Article

\title{
Prevalence, Risk Factors, and Molecular Detection of Campylobacter in Farmed Cattle of Selected Districts in Bangladesh
}

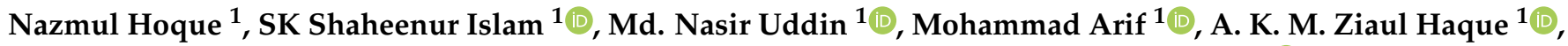 \\ Sucharit Basu Neogi ${ }^{2}$, Md. Mehedi Hossain ${ }^{3}$, Shinji Yamasaki ${ }^{2}$ and S. M. Lutful Kabir ${ }^{1, *(D)}$ \\ 1 Department of Microbiology and Hygiene, Bangladesh Agricultural University, \\ Mymensingh 2202, Bangladesh; nazmulh11@gmail.com (N.H.); s_islam73@live.com (S.S.I.); \\ nasirmbsobug@gmail.com (M.N.U.); mdarif38515@bau.edu.bd (M.A.); \\ vetzia.2004.bd@gmail.com (A.K.M.Z.H.) \\ 2 Graduate School of Life and Environmental Sciences, Osaka Prefecture University, Osaka 598-8531, Japan; \\ sbneogi@yahoo.com (S.B.N.); shinji@vet.osakafu-u.ac.jp (S.Y.) \\ 3 Program Specialist (Livestock), Krishi Gobeshona Foundation (KGF), Dhaka 1215, Bangladesh; \\ mehedi.dls@gmail.com \\ * Correspondence: 1kabir79@bau.edu.bd; Tel.: +88-091-67401-6 (ext. 63218)
}

\section{check for} updates

Citation: Hoque, N.; Islam, S.S.; Uddin, M..N.; Arif, M.; Haque,

A.K.M.Z.; Neogi, S.B.; Hossain, M..M.;

Yamasaki, S.; Kabir, S.M.L.

Prevalence, Risk Factors, and

Molecular Detection of Campylobacter in Farmed Cattle of Selected Districts in Bangladesh. Pathogens 2021, 10, 313. https://doi.org/10.3390/ pathogens 10030313

Academic Editor: Chyer Kim

Received: 13 January 2021

Accepted: 3 March 2021

Published: 7 March 2021

Publisher's Note: MDPI stays neutral with regard to jurisdictional claims in published maps and institutional affiliations.

Copyright: (C) 2021 by the authors Licensee MDPI, Basel, Switzerland. This article is an open access article distributed under the terms and conditions of the Creative Commons Attribution (CC BY) license (https:// creativecommons.org/licenses/by/ $4.0 /)$

\begin{abstract}
A cross-sectional survey was conducted in selected districts of Bangladesh to estimate prevalence, risk factors, and molecular detection of Campylobacter isolates from 540 farmed cattle of 90 herds. As an individual sample, 540 feces, and as a pooled sample, 180 milk samples, 90 feed samples, 90 water samples, 90 manure samples, and 90 animal attendants' hand-rinse water were collected and tested via culture, biochemical, and molecular assays. A pretested semi-structured questionnaire was used to collect herd-level data on risk factors with the herd owners. The herd-level data on risk factors were analyzed through univariate and multivariate analyses, and a $p$-value $<0.05$ was considered statistically significant for all analyses. Overall, farm-level prevalence of bovine Campylobacter was enumerated to be $53.3 \%$ (95\% confidence interval [CI]: $42.5-63.9 \%$ ). The feces sample was found to be a high level of contamination of 30.9\% (95\% CI: 27-35\%) followed by the manure swab (pooled) at $15.6 \%$ (95\% CI: 8.8-24.7\%). Campylobacter jejuni was documented as an abundant species (12.6\%), followed by Campylobacter coli $(5.1 \%)$, and Campylobacter fetus $(0.3 \%)$. Older farms (>5 years of age), no/minimum cleaning and disinfection practices, along with animal roaming outside of the farm, were documented as significant risk factors for farm-level Campylobacter occurrence. Evidence-based control measures need to be taken through stringent biosecurity and hygienic measurement to lessen the load of the Campylobacter pathogen in the farm environment and prevent further transmission to animals and humans.
\end{abstract}

Keywords: farmed cattle; Campylobacter spp.; prevalence; risk factors; PCR; sequencing; Bangladesh

\section{Introduction}

The genus Campylobacter includes a divergent group of Gram-negative bacteria responsible for foodborne gastroenteritis all over the world [1,2]. Over 95 million people infected with foodborne diseases were found to be linked with Campylobacter globally in 2010 [1], and an estimated 1.5 million people get infections with these pathogens each year in the United States [2,3]. The food animals: for example poultry, cattle, sheep, pigs, and ostriches; pets, including dogs and cats; and environmental sources, are associated with human campylobacteriosis [4]. As enteric and zoonotic pathogens, some Campylobacter spp. are well adapted as a commensal in the intestinal tract of various food-producing animals, like ruminants and poultry [5], and act as a reservoir of Campylobacter [4].

Amongst the reservoirs of Campylobacter species, cattle are considered to be the source of transmission of many human bacterial infections [6]. These bacteria, inhabiting the 
gastrointestinal tract of many warm-blooded animals, could excrete through the fecal material of about $20 \%$ of cattle at a concentration of $\sim 3 \times 10^{4} \mathrm{cfu} / \mathrm{g}$ [7]. Farmed cattle infected with Campylobacter spp. may shed the bacteria and increase the risk of introduction of infection into animals and humans via the contaminated settings [8]. The most commonly isolated species are Campylobacter jejuni and Campylobacter coli, as the primary causal agents of bacterial diarrheal disease in high-income countries $[9,10]$. In addition, Gillespie et al. [11] reported that the majority of human intestinal campylobacteriosis $(>90 \%)$ cases are related to $C$. jejuni or C. coli. However, C. fetus is accountable to be a minor contributor of $2.4 \%$ of the total reported cases [12]. The prevalence of $C$. jejuni and C. coli in dairy cattle varies from $5 \%$ to $53 \%$, based on techniques of isolation including relevant determinants such as the age of the animal (young or adult), seasonality, and the type of sample analyzed (feces, intestinal contents, environmental samples, water, manure, etc.).

In Campylobacter spp, several copies of rRNA gene loci, namely 5S, 16S, and $23 S$ rRNA, are occupied in different chromosomal locations [13]; of them, the 16S rRNA gene is specific for Campylobacter DNA and has been widely used for genus identification [14]. Subsequently, the hippuricase (hipO) gene-based polymerase chain reaction (PCR) assay could discriminate C. jejuni from the other species [15]. However, cytolethal distending toxin $(c d t)$ gene-based multiplex PCR is able to accurately identify Campylobacter strains (C. jejuni, C. coli, and C. fetus) [16,17]. This multiplex PCR assay has been found to be simple, fast, and reliable for the evaluation of Campylobacter species [18].

In most cases, human infections are related to the consumption of poultry products, or even direct/indirect contact with animals and birds [19-24]. In addition, contact with animals and animal products to spread of organism among animals and even introduction to humans. Therefore, understanding the distribution of Campylobacter in farmed animals in Bangladesh was very necessary. This study can facilitate formulating fit-for-purpose and practical control programs for the reservoir animals, and minimizing the burden of enteric infection in humans. Additionally, this is particularly important in low and middle-income countries (LMICs), where the epidemiology of these pathogens is poorly understood [25]. There are many studies that have been conducted in Bangladesh relating to the prevalence and risk factors assessment of the pathogen, including molecular detection of Campylobacter in poultry through diversified samplings; nevertheless, detection in cattle yet to be explored. The determinants are normally associated with the Campylobacter prevalence both for herdand animal-level risk factors like herd size, farm with diarrhea, presence of other animals, biosecurity status, farm concentration, season, water supply, type of feed, overcrowding, stress, gender, and weight [26-29]. Identification of the herd-level risk factors connected with the distribution of Campylobacter at the herd and animal levels are required to frame suitable and operative control programs in the low-resource settings.

The temporal variation of C. jejuni incidence in cattle has been observed, with the highest shedding in the summer or winter [30,31]. This seasonal pattern may reflect at the highest level in either fecal shedding in the bovine species or exposure to a common contamination source like grazing land [32,33]. The variation of the temporal distribution of Campylobacter spp. was documented in dairy cattle. However, research on the prevalence of Campylobacter spp. through wide-range sampling in farmed cattle along with molecular detection has not been conducted.

The major changes in livestock rearing, from subsistence herding to the intensive system, has been witnessed since the last decade to minimize the nascent demand of animal origin food [34]. The total livestock population of Bangladesh comprises 24 million cattle, 26 million goats, 3.5 million sheep, 1.5 million buffaloes, and 347 million poultry [35]. Through artificial insemination (AI) with exotic breeds, the productivity of indigenous cattle has been continually increasing since a few decades ago. Therefore, number of crossbred cattle is steadily growing. This practice is leading to the emergence of cattle specific pathogens, like $C$. jejuni lineages, from host-generalized strains. This implies a significant burden of an impotent zoonotic pathogen that can possibly enable human infections [36]. The emergence of such a cattle-adapted Campylobacter pathogen through 
losing the special gene that caused a down-sized genome in the reductive evolution process is widely noticed among bacteria within divergent niches [37]. This is the first conclusive study on Campylobacter in the dairy cattle of Bangladesh through wide-range sampling that confirms the prevalence of Campylobacter spp. in farmed cattle along with molecular detection of the isolates. The study also evaluated the potential herd-level risk factors associated with the occurrence of Campylobacter in the dairy farming practices of Bangladesh.

\section{Results}

\subsection{Dairy Farm Management Descriptive Statistics}

Of the 90 dairy farms, $55.6 \%(n=50)$ and $44.4 \%(n=40)$ were included from Mymensingh and Dhaka districts, respectively, of which nearly $60 \%$ of farms $(n=53)$ were with a herd size of $<20$ cattle. Of the surveyed farmed animals, the majority $(>90 \%)$ were Holstein Frisian crossbred cattle, and the rest of them were Sahiwal or Sindhi/Jersey crossbred cattle. Nearly, two-thirds of the farms $(62.2 \%, n=56)$ were $>5$ years old and $68.9 \%(n=62)$ fed their cattle with prepared feed (noncommercial/ready-made) after purchasing different components. In the meantime, $64.4 \%(n=58)$ of farms used antibiotics supplementation in the cattle feed for prophylactic use. About two-thirds of the farmers $(64.4 \%, n=58)$ had no training on cattle rearing, and $78.9 \%(n=71)$ had no knowledge on risk perception on the Campylobacter infection if their farmed cattle get access to pasture or freely roam outside. More than half of the dairy farms $(57.8 \%, n=52)$ were provided animal health care facilities by non-veterinarian professionals (paraprofessional/quack/farmer himself) (Table 1).

Table 1. Univariate analysis of farm management and environmental factors associated with the herd-level Campylobacter prevalence in cattle farms of Dhaka and Mymensingh districts.

\begin{tabular}{|c|c|c|c|c|c|}
\hline Variables & Category & $\begin{array}{c}\text { Number of Positive } \\
\text { Farms (\%) }\end{array}$ & $\begin{array}{l}\text { Odds } \\
\text { Ratio }\end{array}$ & $\begin{array}{l}\text { 95\% Confidence } \\
\text { Interval (CI) }\end{array}$ & $p$ Value \\
\hline \multirow{2}{*}{ Farm location (District) } & Mymensingh $(n=50)$ & $28(56)$ & 1 & & \multirow[b]{2}{*}{0.57} \\
\hline & Dhaka $(n=40)$ & $20(50)$ & 0.8 & $0.3-1.8$ & \\
\hline \multirow{2}{*}{ Age of the farm } & Up to five years $(n=34)$ & $13(38.2)$ & 1 & & \multirow{2}{*}{0.03} \\
\hline & $>5$ years $(n=56)$ & $35(62.5)$ & 2.7 & $1.1-6.5$ & \\
\hline \multirow{2}{*}{ Animal shed } & $\begin{array}{l}\text { Newly constructed within a year } \\
\qquad(n=24)\end{array}$ & $8(33.3)$ & 1 & & \multirow{2}{*}{0.021} \\
\hline & Old (more than one year) $(n=66)$ & $40(60.6)$ & 3.1 & $1.1-8.2$ & \\
\hline \multirow{2}{*}{ Farm (herd) size } & Up to 20 cattle $(n=53)$ & $28(52.8)$ & 1 & & \multirow[b]{2}{*}{0.90} \\
\hline & $>20$ cattle $(n=37)$ & $20(54.0)$ & 1.1 & $0.4-2.4$ & \\
\hline \multirow{2}{*}{ Stocking density } & More than 50 sq. ft. /animal $(n=49)$ & $18(36.7)$ & 1 & & \multirow[b]{2}{*}{0.63} \\
\hline & Less than $50 \mathrm{sq} . \mathrm{ft}$./animal $(n=41)$ & $23(56.1)$ & 1.2 & $0.5-2.8$ & \\
\hline \multirow{2}{*}{ Milking type } & Machine milking $(n=5)$ & $2(40)$ & 1 & & \multirow[b]{2}{*}{0.53} \\
\hline & Hand milking $(n=85)$ & $46(54.1)$ & 1.7 & $0.3-11.1$ & \\
\hline \multirow{2}{*}{ Feed used } & Readymade feed $(n=28)$ & $15(53.6)$ & 1 & & \multirow{2}{*}{0.975} \\
\hline & Prepared by farmer $(n=62)$ & $33(53.2)$ & 0.9 & $0.4-2.4$ & \\
\hline \multirow{2}{*}{ Farmers' training } & Yes $(n=32)$ & $11(34.4)$ & 1 & & \multirow{2}{*}{0.0007} \\
\hline & No $(n=58)$ & $37(63.8)$ & 3.4 & $1.4-8.3$ & \\
\hline \multirow{4}{*}{$\begin{array}{c}\text { Knowledge on risk perception of cattle access } \\
\text { outside or freely roaming } \\
\text { Cattle handler type }\end{array}$} & Yes $(n=19)$ & $5(26.3)$ & 1 & & \\
\hline & No $(n=71)$ & $43(60.6)$ & 4.3 & $1.4-13.3$ & 0.007 \\
\hline & Family member $(n=28)$ & $16(57.1)$ & 1 & $0.3-1.9$ & 0.62 \\
\hline & Employee $(n=62)$ & $32(51.6)$ & 0.8 & & \multirow{3}{*}{0.68} \\
\hline \multirow{2}{*}{ Prophylactic use of antibiotics } & Yes $(n=58)$ & $30(51.7)$ & 1 & $0.50-2.8$ & \\
\hline & No $(n=32)$ & $18(56.2)$ & 1.2 & & \\
\hline \multirow{2}{*}{ Animal health care provider } & \multirow{2}{*}{$\begin{array}{l}\text { Registered veterinarian }(n=38) \\
\text { Non-vet (para professional/quack/ } \\
\text { farmer himself) }(n=52)\end{array}$} & $15(39.5)$ & 1 & $1.1-6.3$ & \multirow[t]{2}{*}{0.02} \\
\hline & & $33(63.5)$ & 2.7 & & \\
\hline \multirow{2}{*}{ Floor condition } & Dry $(n=78)$ & $37(47.4)$ & 1 & & \multirow{3}{*}{0.004} \\
\hline & Wet $(n=12)$ & $11(91.7)$ & 12.2 & $1.5-90.0$ & \\
\hline \multirow{2}{*}{ Sunlight accessibility in the cattle shed } & Yes $(n=86)$ & 45 (52.3) & 1 & & \\
\hline & No $(n=4)$ & $3(75)$ & 2.7 & $0.3-27.3$ & 0.37 \\
\hline
\end{tabular}

2.2. Prevalence of Campylobacter spp.

2.2.1. Farm-Level Prevalence

Among the 90 farms, 48 were found to be positive with Campylobacter spp. overall via culture and biochemical tests, and finally, molecular assays (PCR). Therefore, a herd-/farmlevel prevalence was confirmed as 53.3\% (95\% CI: 42.5-63.9\%), which represented $56 \%$ (95\% CI: $41.3-70 \%$ ) and 50\% (95\% CI: 33.8-66.2\%) in the Mymensingh and Dhaka districts, 
respectively (Table 2). However, herd-level sub-district (Upazila) prevalence ranged from $33.3 \%$ to $100 \%$. No significant variation was observed in the herd- level Campylobacter spp. distribution among districts and sub-districts (Upazila) with a $p$ value of $>0.05$ (Table 2).

Table 2. Prevalence of Campylobacter spp. in dairy cattle herds/farms and different types of samples in two districts (Dhaka and Mymensingh).

\begin{tabular}{|c|c|c|c|c|}
\hline Variable & Positive & Prevalence (\%) & 95\% Confidence Interval & $p$ Value \\
\hline Number of herd /farms $(N=90)$ & 48 & 53.3 & $42.5-63.9$ & - \\
\hline \multicolumn{5}{|l|}{ District } \\
\hline Mymensingh $(n=50)$ & 28 & 56 & $41.3-70$ & \multirow[b]{2}{*}{0.57} \\
\hline Dhaka $(n=40)$ & 20 & 50 & $33.8-66.2$ & \\
\hline \multicolumn{5}{|l|}{ Sub-districts/city corporation area } \\
\hline Sadar Mymensingh $(n=26)$ & 15 & 57.7 & $36.9-76.6$ & \multirow{9}{*}{0.64} \\
\hline Muktagacha $(n=6)$ & 2 & 33.3 & $4.3-77.7$ & \\
\hline Trisal $(n=6)$ & 5 & 83.3 & $35.9-99.6$ & \\
\hline Bhaluka $(n=4)$ & 2 & 50.0 & $6.8-93.2$ & \\
\hline Gouripur $(n=3)$ & 2 & 66.7 & $9.4-99.2$ & \\
\hline Fulbaria $(n=5)$ & 2 & 40.0 & $5.3-85.3$ & \\
\hline Savar $(n=14)$ & 7 & 50.0 & $23-77$ & \\
\hline Dhamrai $(n=2)$ & 2 & 100.0 & $15.8-100$ & \\
\hline Dhaka City Corporation $(n=24)$ & 11 & 45.8 & $25.5-67.1$ & \\
\hline \multicolumn{5}{|l|}{ Sample type } \\
\hline Feces $(n=540)$ & 167 & 30.9 & $27-35$ & \multirow{7}{*}{0.000} \\
\hline $\operatorname{Milk}(n=180)$ & 3 & 1.7 & $0.3-4.8$ & \\
\hline Feed $(n=90)$ & 0 & 0 & $0-4$ & \\
\hline Water $(n=90)$ & 0 & 0 & $0-4$ & \\
\hline Manure swab $(n=90)$ & 14 & 15.6 & $8.8-24.7$ & \\
\hline Hand-rinse water of animal attendants $(n=90)$ & 10 & 11.11 & $5.5-19.5$ & \\
\hline Overall $(N=1080)$ & 194 & 18 & $15.7-20.4$ & \\
\hline \multicolumn{5}{|l|}{ Animal category } \\
\hline Calves $(n=180)$ & 51 & 28.3 & $21.9-35.5$ & \multirow{3}{*}{0.0008} \\
\hline Heifers $(n=180)$ & 42 & 23.3 & $17.4-30.2$ & \\
\hline Cows $(n=180)$ & 74 & 41.1 & $33.8-48.7$ & \\
\hline Total sample $(N=540)$ & 167 & 30.9 & $27-35$ & \\
\hline \multicolumn{5}{|l|}{ Season } \\
\hline Pre-monsoon (March-May) $(n=300)$ & 87 & 29 & $23.9-34.5$ & \multirow{3}{*}{0.47} \\
\hline Monsoon (June-October) $(n=156)$ & 54 & 34.6 & $27.2-42.6$ & \\
\hline Winter (November-February) $(n=84)$ & 26 & 31 & $21.3-42$ & \\
\hline
\end{tabular}

$n=$ number of herds, samples (in each category), $N=$ total number of farms/samples, $\mathrm{CI}=$ confidence interval.

\subsubsection{Sample-Level Prevalence}

The different samples $(N=1080)$ that comprised the individual sample are as follows: the overall sample of feces $(n=540)$ and pooled samples of milk $(n=180)$, feed $(n=90)$, water $(n=90)$, manure swab $(n=90)$ and hand-rinse water of the animal attendants $(n=90)$ were collected from 90 dairy farms. Of the 1080 samples, 207 were found to be provisionally positive via a culture-based method, and finally, 194 samples were confirmed as Campylobacter spp. by biochemical and molecular tests (Supplementary Figure S2); therefore, an overall sample-level prevalence of $18 \%(194 / 1080)$ was confirmed. The highest prevalence was observed in feces (30.9\%) (as an individual sample), followed by manure and hand-rinse water as $15.6 \%$ and $11.1 \%$, respectively (as pooled samples). The feed and water samples were found to be a non-contamination status in this study. The distribution of Campylobacter spp., in different categories of the sample was found to be associated with the Campylobacter positive status $(p=0.000)$. In this study, the highest prevalence was observed in cows $(41.1 \%)$, followed by calves $(28.3 \%)$, and heifers $(23.3 \%)$; this animal-level distribution was found to be statistically significant $(p=0.0008)$ through feces sample evaluation. The highest occurrence of Campylobacter (34.6\%) was captured in the monsoon season, followed by winter (31\%), and pre-monsoon season $(29 \%)$. However, 
these temporal variations were found to be non-significant in this study (Table 2 and Table S1).

\subsection{Molecular Detection of Campylobacter spp.}

All Campylobacter isolates (194) presented a specific amplification of $1530 \mathrm{bp}$ fragment size via a genus-specific (16S rRNA gene) polymerase chain reaction (PCR) (Figure S1-a), and further molecular detection for C. jejuni was accomplished by a hipO gene-based PCR that generated an amplicon size of 735 bp (Figure S1-b).

Finally, $c d t A$ gene-based multiplex PCR was carried out for the detection of C. jejuni, C. coli, and C. fetus. In this PCR assay, C. jejuni, C. coli, and C. fetus generated 631 bp, 329 bp, and 489 bp amplicon sizes, respectively, as a confirmatory test for species identification (Figure S1-c). Additionally, among the PCR-positive isolates (194), C. jejuni $(n=17)$, C. coli $(n=1)$, and $C$. fetus $(n=3)$ were used for partial sequencing of the $16 \mathrm{~S}$ ribosomal RNA (16S rRNA) gene, and the interpretation of the sequencing data validated the PCR results. Moreover, the sequences that produced significant alignments were used in the Basic Local Alignment Search Tool (BLAST) analysis, and our study isolates represented an identity of 99.55-100\%, 99.79-100\% and 96.87-100\% for C. jejuni, C. coli, and C. fetus, respectively.

The data of the partial sequence of the 16S rRNA genes were submitted in the GenBank and the accession numbers were obtained accordingly as C. jejuni: H3/ MT782639, H1/MT783398, B1/MT784200, B2/MT784199, B4/MT783401, B3/MT783402, D8/MT783426, D12/MT783690, D2/MT784146, D1/MT784147, D4/MT784163, D7/MT784192, D6/MT784193, D5/MT784195, D13/MT784196, D10/MT784197, D9/MT784198; C. coli: H2/MT774557; and C. fetus: B5/MT783400, D3/ MT783688, D11/MT783689.

In this study, among the 194 isolates, $70.1 \%(n=136), 28.4 \%(n=55)$, and $1.5 \%(n=3)$ were confirmed as C. jejuni, C. coli, and C. fetus, respectively. The distribution of C. jejuni, C. coli, and C. fetus were captured as 12.6\% (95\% CI: 10.7-14.7\%), 5.1\% (95\% CI: 3.9-6.6\%), and $0.3 \%$ (95\% CI: $0.1-0.8 \%$ ), respectively, in the different samples (Figure 1).

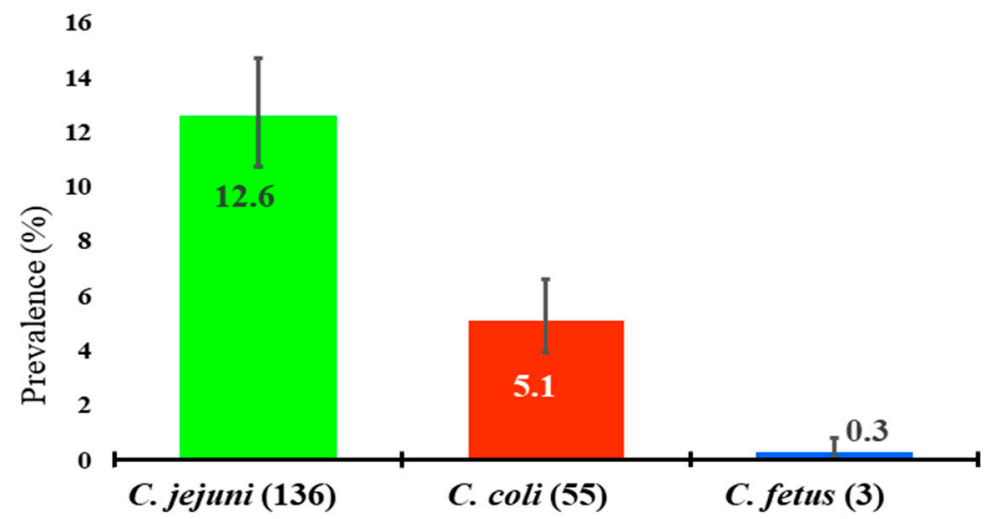

Figure 1. Distribution of isolates $(n=194)$ of Campylobacter spp. with $95 \%$ confidence interval (CI) that represented the prevalence of $C$. jejuni, C. coli, and C. fetus as $12.6 \%, 5.1 \%$, and $0.3 \%$, respectively, in selected dairy farms confirmed through $16 \mathrm{~S}$ rRNA, hippuricase (hipO), and $c d t A$ gene-based polymerase chain reaction (PCR) assays. 


\subsection{Evaluation of Risk Factors}

\subsubsection{Univariate Analysis}

A total of 24 determinants (Table S3) relating to farm management, environmental factors, and biosecurity and hygienic practices were used in univariate analysis. In univariate analysis, farm management and environmental determinants, namely, the age of the farm, the farmers' training, knowledge on risk perception of animals roaming outside of the farm, animal health service provider, and the floor condition of cattle shed were significantly associated with the herd-level Campylobacter status (Table 1). Additionally, biosecurity-related determinants like cleaning and disinfection practices (C\&D), other animals' access (birds/goats/sheep/wild animals) to the farm, and animals roaming outside of the farm were confirmed as significant risk factors for Campylobacter status in invariable analysis (Table 3).

Table 3. Univariable analysis of biosecurity-related factors of the herd-level Campylobacter spp. positivity status in farmed cattle farms of Dhaka and Mymensingh districts.

\begin{tabular}{|c|c|c|c|c|c|}
\hline Variables & Category & $\begin{array}{l}\text { Number of Positive } \\
\text { Farms (\%) }\end{array}$ & OR & $95 \% \mathrm{CI}$ & $p$-Value \\
\hline \multirow{2}{*}{$\begin{array}{l}\text { Cleaning and disinfection practices (floor cleaning, } \\
\text { cleaning of manger, and drink regularly) }\end{array}$} & Good practices $(n=60)$ & $26(43.3)$ & 1 & & \\
\hline & Poor/no practices $(n=30)$ & $22(73.3)$ & 11.2 & $3.5-36.4$ & 0 \\
\hline \multirow{2}{*}{ Worker boot disinfection } & Yes $(n=12)$ & $6(50)$ & 1 & & \\
\hline & No $(n=78)$ & $42(53.8)$ & 1.2 & $0.3-3.9$ & 0.8 \\
\hline \multirow{2}{*}{ Isolation of animal } & Yes $(n=19)$ & $9(47.4)$ & 1 & & \\
\hline & No $(n=71)$ & $39(55)$ & 1.3 & $0.5-3.7$ & 0.55 \\
\hline \multirow{2}{*}{$\begin{array}{l}\text { Access of other animals (poultry/goats/sheep/wild } \\
\text { animals) in the farm }\end{array}$} & No $(n=58)$ & $26(44.8)$ & 1 & & \\
\hline & Yes $(n=32)$ & $22(68.7)$ & 2.7 & $1.1-6.7$ & 0.03 \\
\hline \multirow{2}{*}{ Udder cleaning } & With antiseptic $(n=14)$ & $8(57.1)$ & 1 & & \\
\hline & With water $(n=76)$ & $40(52.6)$ & 0.8 & $0.2-2.6$ & 0.75 \\
\hline \multirow{2}{*}{ Manure storage } & Solid $(n=32)$ & $15(46.9)$ & 1 & & \\
\hline & Semi-solid $(n=58)$ & $33(56.9)$ & 1.5 & $0.6-3.6$ & 0.36 \\
\hline \multirow[b]{2}{*}{ Animal roams outside of the farm } & No $(n=21)$ & $1(4.7)$ & 1 & & \\
\hline & Yes $(n=69)$ & $47(68.1)$ & 42.7 & $5.4-339.0$ & 0 \\
\hline \multirow{2}{*}{ Cattle feces use purpose } & Fertilizer $(n=41)$ & $22(53.7)$ & 1 & & \\
\hline & Aquaculture $(n=49)$ & $26(53.1)$ & 0.9 & $0.4-2.2$ & 0.95 \\
\hline \multirow{2}{*}{ History of diarrhea in the farmed cattle } & No $(n=84)$ & $45(53.6)$ & 1 & & \\
\hline & Yes $(n=6)$ & $3(50)$ & 0.9 & $0.1-4.5$ & 0.86 \\
\hline \multirow{2}{*}{ Interface (Share same premices with cattle) } & No $(n=70)$ & $40(57.1)$ & 1 & & \\
\hline & Yes $(n=20)$ & $8(40)$ & 0.5 & $0.2-1.4$ & 0.175 \\
\hline
\end{tabular}

OR: odds ratio, CI: confidence interval.

\subsubsection{Multivariate Analysis}

Among the risk factors, nine were included in the multivariable logistic regression analysis, as these were found to be statistically significant in univariate analysis. The risk factors for herd-level Campylobacter status were identified in the final multivariable logistic regression model. The most important risk factors associated with Campylobacter positive status were identified as older farms (more than 5 years), no/minimum cleaning and disinfection practices, and animals roaming outside (Table 4). The odds of Campylobacter positive status were 10.6 times $(95 \% \mathrm{CI}=1.9-59.8, p=0.0007)$ higher in a cattle farm with an age of $>5$ years compare to a cattle farm of the age of $1-5$ years. The cattle farm had no/minimum cleaning and disinfection practices had 12.4 times (95\% CI: 2.1-71.6, $p=0.0048$ ) higher risk to be Campylobacter positive status. The farms with roaming animals were 44.0 times ( $95 \%$ CI: 3.6-537.0, $p=0.0048$ ) more likely to be positive with Campylobacter compared to farms with no roaming animals (Table 4). 
Table 4. Multivariable logistic regression analysis of potential risk factors with the herd-level Campylobacter spp. positivity status in cattle farms of Dhaka and Mymensingh districts.

\begin{tabular}{|c|c|c|c|c|c|}
\hline Risk Factors & Category & AOR & $95 \%$ CI & SE & $p$ Value \\
\hline \multirow[t]{2}{*}{ Age of the farm } & $1-5$ years & 1 & & & \\
\hline & $>5$ years & 10.6 & $1.9-59.8$ & 0.882 & 0.0007 \\
\hline \multirow[t]{2}{*}{ Animal shed } & Newly constructed & 1 & & & \\
\hline & Old & 4.0 & $0.8-19.9$ & 0.82 & 0.09 \\
\hline \multirow[t]{2}{*}{ Training } & Yes & 1 & & & \\
\hline & No & 3.9 & $0.7-21.2$ & 0.861 & 0.112 \\
\hline \multirow[t]{2}{*}{ Knowledge } & Yes & 1 & & & \\
\hline & No & 3.5 & $0.4-28.5$ & 1.06 & 0.23 \\
\hline \multirow{2}{*}{ Cleaning and disinfection practices } & Good practices & 1 & & & \\
\hline & No/minimum practices & 12.4 & $2.1-71.6$ & 0.893 & 0.0048 \\
\hline \multirow[b]{2}{*}{ Floor Condition } & Dry & 1 & & & \\
\hline & Wet & 2.0 & $0.1-56.3$ & 1.69 & 0.67 \\
\hline \multirow{2}{*}{ Animals roaming outside } & No & 1 & & & \\
\hline & Yes & 44.0 & $3.6-537.10$ & 1.27 & 0.003 \\
\hline \multirow{2}{*}{$\begin{array}{l}\text { Other animal (poultry/goat/sheep/wild } \\
\text { animal) access }\end{array}$} & No & 1 & & & \\
\hline & Yes & 3.1 & $0.6-16.1$ & 0.84 & 0.178 \\
\hline \multirow{2}{*}{ Animal health service provider } & Registered veterinarian & 1 & & & \\
\hline & Quack/farmer himself & 3.1 & $0.6-16.3$ & 0.84 & 0.174 \\
\hline
\end{tabular}

AOR: adjusted odds ratio; CI: confidence interval; SE: standard error.

\section{Discussion}

In this study, we evaluated herd-level Campylobacter status in the light of prevalence and the molecular detection of Campylobacter isolates, and assessed the risk factors for herd-level occurrence in the farmed animal in two cattle-dominant districts in Bangladesh. We evaluated the overall herd-/farm- and sample-level prevalence of Campylobacter spp. as $53.3 \%(48 / 90)$ and $18 \%(194 / 1080)$, respectively. However, several studies in different geographical locations confirmed high herd-level prevalence of $C$. jejuni and/or C. coli as $78.8 \%$ in beef cattle and $86.6 \%$ in dairy cattle in northern Spain [38]. Moreover, a low herd-level prevalence (33\%) was reported in Austria [28].

A high level of prevalence of Campylobacter spp. in feces (30.9\%, 167/540) among all categories of the tested sample was documented. This finding is consistent with an earlier study conducted in Bangladesh, as the prevalence of Campylobacter spp. was documented as $26.7 \%$ and $20 \%$ in feces and milk samples, respectively, that were collected from cattle $(n=40)$ [39]. This finding is consistent with a study conducted in Odisha, India, in which $25.33 \%$ of fecal samples collected from farmed animals (cow, sheep, and goats) showed the prevalence of Campylobacter spp. [40]. A high-level prevalence of Campylobacter spp. in feces was reported in different studies as $87 \%, 69.1 \%, 78 \%, 66.7 \%$, and $78.5 \%$ in Canada, France, Sweden, Basque Country, and Lithuania, respectively [26,41-44]. However, lower levels of prevalence were confirmed in Asian countries, as $14 \%$ in dairy cows in Thailand [45] and $1.6 \%$ in buffaloes in Lao People's Democratic Republic [46]. Moreover, a low-level of prevalence of $14.9 \%$ in feces was recorded in Austria [28]. However, because of limited published reports on Campylobacter distribution in farmed cattle, this evaluation was not fit to compare in Bangladesh.

We confirmed the prevalence of C. jejuni, C. coli, and C. fetus for 12.6\% (136/1080), $5.1 \%(55 / 1080)$, and $0.3 \%(3 / 1080)$ of samples, respectively. However, higher prevalence of C. jejuni was detected as $25.6 \%$ from a dairy farm sample in Korea [47] and $69 \%$ from beef cattle feces in Canada [26]. Among the isolates, we verified that 70\% (136/194), 28\% (55/194), and $2 \%(3 / 194)$ were from C. jejuni, C. coli, and C. fetus, respectively. This result is consistent with the findings of a study conducted in Sweden [42], as $61 \%$ of isolates were C. jejuni, including a negligible proportion of isolates $(0.7 \%)$ that were confirmed as C. coli, which disagreed with our study findings. Moreover, the present study confirmed $11.1 \%$ $(10 / 90)$ of the hand-rinse water of the animal attendants was found to be contaminated 
with Campylobacter spp. Therefore, our study findings present the wide distribution of Campylobacter spp. in farm settings that might be responsible for the transmission among animals, from animals to humans, or even prevalence that is successfully maintained within the farms' environments.

The study documented that $15.6 \%$ (14/90) of manure (pooled) samples were positive with Campylobacter spp., and the proportion of C. jejuni was found to be higher $(70 \%$, 136/194) than the other isolates. C. jejuni survives at lower temperatures, rather than at higher temperatures, which signifies the risk of contamination to other foodstuffs [48]. Moreover, studies have confirmed that Campylobacter are able to survive in a very harsh environment, like a hot and humid environment, or even in a manure compost pit [49,50]. These factors would facilitate to the subsistence of Campylobacter in the farm environment for a longer period of time.

In this study, 1.7\% (3/180) milk samples were found to be contaminated with Campylobacter spp. A few studies confirmed the high level of milk filter samples that were positive with Campylobacter as 14\% and 13\% in Sweden [42,51]. Studies have established the risk of the introduction of Campylobacter spp. through the consumption of raw milk in different geographic locations [52-55].

The farm-level prevalence of Campylobacter spp. did not differ among the districts $(p=0.57)$ and sub-districts $(p=0.64)$. However, the sample-level prevalence of Campylobacter spp. was found to be significant $(p=0.000)$. The distribution of Campylobacter for different age groups (cows, heifers, and calves) of cattle was assessed significant ( $p=0.0008$ ) (Table 3). In this survey, approximately one-third of cattle farms $(30.9 \%)$ were found to be positive with Campylobacter by feces sample evaluation. This could be a source of infection for humans through direct contact $[56,57]$ or environmental contamination. In this regard, control measures need to be adopted through mandatory cleaning and disinfection practices. The odds of becoming Campylobacter positive were 12.4 times higher with farms that had poor to no cleaning and disinfection practices. This finding is supported by another study as low-to-moderate cleaning and disinfection practices had 9.24 times more likelihood to be Campylobacter positive [47]. Appropriate hygienic measurements in cattle farm and milking points, and cleanliness practices of dairy cattle sheds, can reduce the growth and subsequent transmission of Campylobacter spp. [43,58,59].

Farmed animals allowed to freely roam outside and pasture graze increase the likelihood of exposure to multiple sources of contamination [43]. The farms with freely roaming animals have more probability ( $\mathrm{AOR}=44.0,95 \% \mathrm{CI}$ : 3.6-537.1, $p=0.003$ ) to be positive with Campylobacter spp. This finding is supported by other researchers who showed that grazing cattle have a higher likelihood to be positive with Campylobacter infection [60,61]. The present study confirmed that older farms ( $>5$ years) are more likely to be Campylobacter positive. This might be potential to successful maintenance of organisms for a longer period of time if cleaning and disinfection practices are not performed properly in the cattle farm. The fact that older broiler farms (>15 years) have a higher likelihood of Campylobacter occurrence was established in six European countries [62]. However, due to lack of reference data in cattle that makes inconclusive our study findings to compare. In this study, the occurrence of Campylobacter in dairy farms was found to be marginally higher in the monsoon season compared to the winter and the pre-monsoon seasons, but this was found to be non-significant. The temperature variation in different seasons is minimum, as Bangladesh has a hot, humid, warm, tropical climate with mild winters [63], which might lead to the non-significance of temporal impact on the variation of Campylobacter occurrence at the farm level.

In this study, some potential variables were shown to be non-significant with the farm-level Campylobacter status in the multivariable logistic regression model, i.e., the animal shed, farmers' training, knowledge, the animal health care provider, the floor condition, and access of other animals (poultry/goats/sheep/wild animals). Farmers' knowledge of risk perception on how Campylobacter is released, maintained, and transmitted is needed as compliance with the biosecurity practices [64]. The training of animal 
attendants / farmers related to biosecurity and hygienic measurement has been documented to reduce Campylobacter exposure and further maintenance at the farm level $[65,66]$. Animal health care services (vaccination, medication) provided through non-veterinarians (paraprofessional/quack/farmer) were found to be risky practices that were likely to be associated with Campylobacter infection [67]. Access by other animals (poultry/goats/sheep/wild animals) in the farm premises facilitates to the introduction of Campylobacter was also investigated [28].

The study confirmed herd-level Campylobacter spp. status on the basis of feces sample evaluation. However, several pooled samples, like swabs from the manure pit, water, feed, and the hand-rinse water from cattle attendants, were collected from the same herd during sampling to confirm the feces test results. This also signifies a diverse distribution of Campylobacter species within the same group (herd) of cattle. This study depicts the levels of Campylobacter distribution in dairy farming practices that included the herd-and animal-level occurrence with potential risk factors. This signifies that source tracing of Campylobacter spp. in food animals is necessary. There is an urgent need for surveillance of Campylobacter in the farm environment, as they change with time [68], and host-generalized strains may develop through intensive cattle farming [36] as the farmed cattle population gradually increases in Bangladesh. Therefore, appropriate preferences to lessen the burden of Campylobacter through good farming practices that include biosecurity and hygienic practices and better management of cattle excreta are needed.

This study has a few limitations, as the culture evaluation and subsequent molecular detection were done using a single colony from each sample of the subculture. This signifies the samples with more than one species of Campylobacter could not be identified under this study, and the blood agar-negative samples did not culture in the broth-based media, which may have reduced the sensitivity of our primary evaluation of Campylobacter. The study mostly used herd-level determinants for identifying the Campylobacter positive status, which created tailbacks to explore the risk factors conclusively. Therefore, a future study including all levels of risk factors for confirming the determinants of Campylobacter occurrence in dairy cattle, and corresponding sampling in humans, is warranted.

\section{Materials and Methods}

\subsection{Study Location, Design, and Survey Farms}

A cross-sectional survey was conducted in commercial crossbred (Holstein Frisian \& Shahiwal Crossbred) farmed cattle of Dhaka and Mymensingh districts from April 2018 to May 2020 (Figure 2). The study sites were selected on the basis of animal distribution, as these districts are considered to be promising cattle-rearing zones of Bangladesh. There are 226,000 and 923,000 heads of cattle in Dhaka and Mymensingh districts, respectively [69], of which 15\% are crossbred cattle [70]. Six sub-districts (Mymensingh Sadar, Muktagacha, Gouripur, Fulbaria, Trisal, and Bhaluka) from the Mymensingh district, and two subdistricts (Savar and Dhamrai) and the Dhaka City Corporation (DCC) area from the Dhaka district were included in this survey. There are around 300 registered dairy farms in the two districts, of which 90 farms from the districts (Mymensingh: 50; Dhaka: 40) were randomly surveyed after consultation with local (sub-district/municipality) livestock offices.

\subsection{Face-to-Face Data Collection in Field Survey}

A pretested semi-structured questionnaire (Table S3) was designed and used for data collection from farmers / farm attendants during sampling from the farm. The questionnaire had 24 questions in two broad areas: (i) variables related to farm management and environment factors (15 questions); (ii) factors related to farm biosecurity and hygienic measurements (9 questions). The questionnaire was translated into local dialects and used in a face-to-face interview session so that the respondent could easily understand its content. However, some data were collected through the field observation/ transect walk method. The responses from the respondents were coded and recorded in Excel spreadsheets for further analysis (Table S2). 


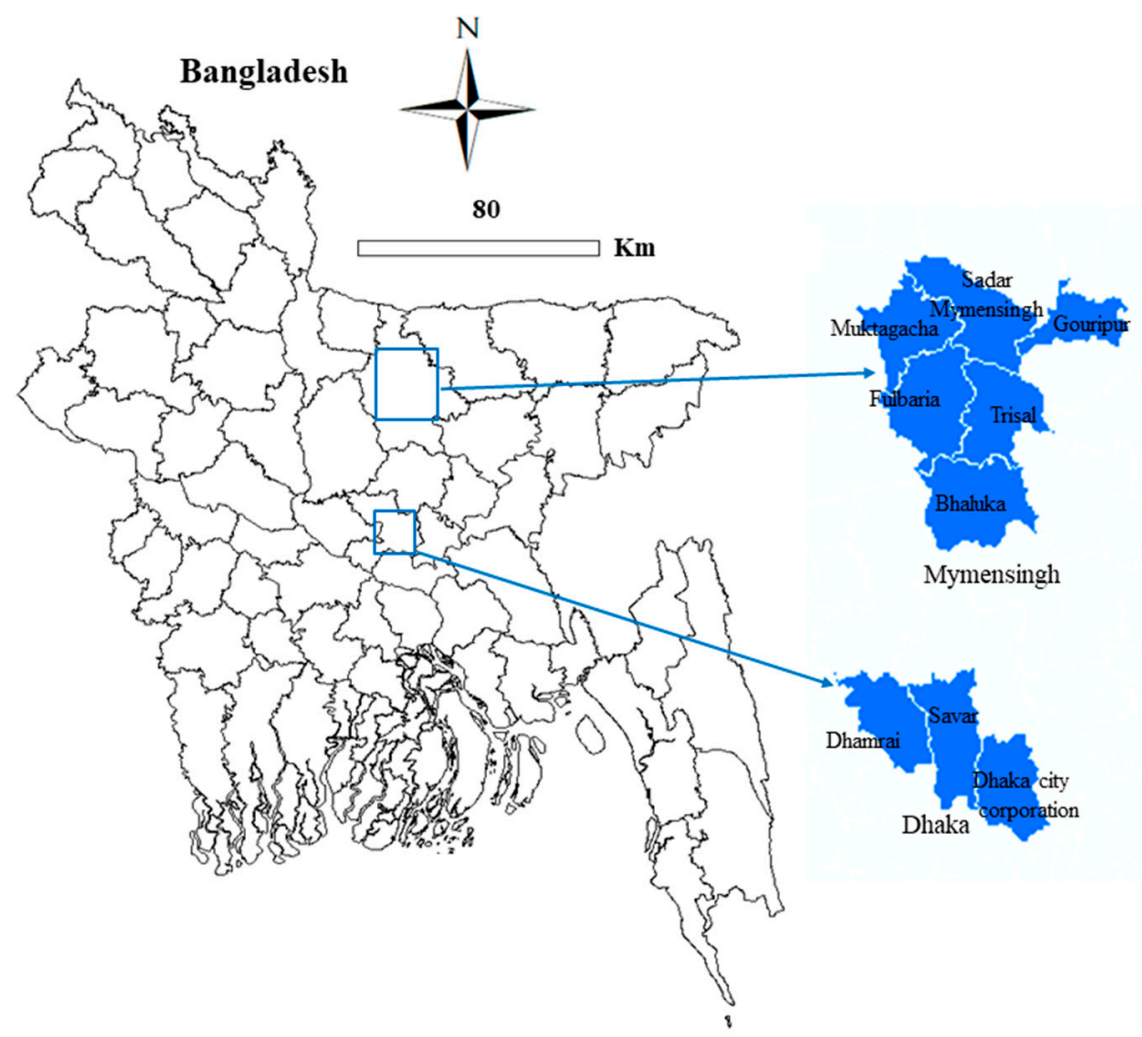

Figure 2. Location of study districts (Mymensingh and Dhaka). A total of six sub-districts (Mymensingh Sadar, Muktagacha, Gouripur, Fulbaria, Trisal, and Bhaluka) of the Mymensingh district and two sub-districts (Dhamarai and Savar) and the Dhaka City Corporation (DCC) area of the Dhaka district were included in this study.

\subsection{Sample Size and Sampling Procedure}

\subsubsection{Sample Size Calculation}

Multi-stage random sampling was done in this study through an initial selection of farms, and subsequently, sampling was done in different categories (calves, heifers, and cow) of animals. The sample size was calculated using the formula given below Equation (1) [71].

$$
n=Z^{2} p(1-p) / d^{2}(1)
$$

where $n$ denotes the required sample size, $Z^{2}$ is the $Z$-score at a $95 \%$ confidence interval or 1.96, $p$ is the expected prevalence of Campylobacter at the animal level $(27 \%=0.27)$ [39], and $d$ is desired absolute precession $(4 \%=0.04)$; thus, a sample size of 474 was obtained. However, we included 540 animals for sampling from the two study districts.

\subsubsection{Sample Collection from Animals}

A total of six individual animal fecal samples were collected from each farm that consisted of two from cows, two from heifers, and two from calves. Additionally, as pooled samples, milk $(n=2)$, feed $(n=1)$, water $(n=1)$, manure swabs $(n=1)$, and the hand-rinse water of farmers/farm attendants $(n=1)$, were collected from each farm. To avoid sampling bias in each pool sample category of feed, water, manure, and hand-rinse water, three sub-samples were randomly collected and pooled together as the "pooled sample". In sum, 1080 samples were collected from 90 dairy farms that comprised 540 feces (as an individual sample) samples, and 180 milk, 90 water, 90 feed, and 90 animal attendants' hand-rinse water samples (as pooled sample) that were collected from the two districts (Table S1). Herd-level prevalence was confirmed on the basis of the feces sample evaluation status, and the status of the pooled samples was evaluated to verify the herd-level occurrence. 
Aseptic precautions were maintained during the collection of the samples. The amount of sample varied according to the sample type as a 1-5 $\mathrm{mL}$ or $\mathrm{g}$ swab material for the feces and manure swab samples, $100 \mathrm{~g}$ for the feed sample, and $100 \mathrm{~mL}$ each for the water, hand-rinse water, and milk samples. The swab samples were preserved and transported in Cary-Blair transport media. Samples were retained in a plastic container $(100 \mathrm{~mL}$ falcon tubes and plastic polybags) immediately after collection with a given unique identification number, and transferred to the laboratory of the Department of Microbiology and Hygiene, Bangladesh Agricultural University (BAU), Mymensingh, while maintaining a cool chain at $4-6{ }^{\circ} \mathrm{C}$.

\subsection{Laboratory Evaluation}

\subsubsection{Culture and Biochemical Tests}

All samples were analyzed individually by filtration method using the cellulose filter with a porosity of $0.45 \mu \mathrm{m}$ (Biotech, Göttingen, Germany). This size is effective to hold $90 \%$ of cells [72] with high-flow rates and enable the best colony growth. The culture of Campylobacter was carried out in selective media with the procedure described earlier [72] with little modification. Briefly, $100 \mu \mathrm{L}$ of each collected sample was spread on the filters that were placed on the surface of blood agar base no. 2 (HiMedia, Mumbai, India) (supplemented with 5\% sheep blood), with Skirrow supplement (for both C. jejuni and C. coli) (HiMedia) and/or with growth supplement (for C. fetus) (HiMedia) and allowed to stand for $30 \mathrm{~min}$ at room temperature. After $30 \mathrm{~min}$ we removed the filter from the Skirrow and/or growth supplement blood agar and then incubated the plates at $37{ }^{\circ} \mathrm{C}$ for $48 \mathrm{~h}$ in microaerophilic conditions $\left(5 \% \mathrm{O}_{2}, 10 \% \mathrm{CO}_{2}\right.$, and $\left.85 \% \mathrm{~N}_{2}\right)$ using AnaeroPouch ${ }^{\circledR}$-MicroAero (Mitsubishi Gas Chemical Co., Inc., Tokyo, Japan). After $48 \mathrm{~h}$, the incubated media were then examined for the growth of bacteria. Grey, flat, and irregularly spreading colonies were observed on the surface of the media. The colonies were then subjected to Gram's Method of staining and observed under a microscope for Gram-negative curves. The selected colonies from the selective agar media were then subcultured onto the supplemented blood agar base no. 2 to obtain a single and pure colony. Differentiation of isolated Campylobacter spp. based on growth characteristics including biochemical tests, such as the catalase test, oxidase test, and hippurate hydrolysis test, were performed according to the standard procedures described earlier [73-75].

\subsubsection{Molecular Detection through PCR}

Culture-positive isolates were further confirmed as Campylobacter spp. by biochemical tests and PCR assays. The DNA was extracted from the pure culture of Campylobacter spp. by boiling method [76]. The genus of Campylobacter was verified through the amplification of the 16S rRNA gene using oligonucleotide primers, as per the procedure described in Table 5 [76].

Table 5. Primers and conditions used for the various PCR assays and sequences.

\begin{tabular}{|c|c|c|c|c|c|c|c|}
\hline \multirow{2}{*}{ Primers } & \multirow{2}{*}{ Sequence $\left(5^{\prime}-3^{\prime}\right)$} & \multirow{2}{*}{ Target/Purpose } & \multirow{2}{*}{ Amplicon Size (bp) } & \multicolumn{3}{|c|}{ PCR Condition (30 cycle) } & \multirow{2}{*}{ Reference } \\
\hline & & & & Denaturation & Annealing & Extension & \\
\hline $\begin{array}{l}16 \mathrm{~S} 9 \mathrm{~F} \\
16 \mathrm{~S} 1540 \mathrm{R}\end{array}$ & $\begin{array}{l}\text { GAGTTTGATCCTGGCTC } \\
\text { AAGGAGGTGATCCAGCC }\end{array}$ & 16S rRNA & 1530 & $94^{\circ} \mathrm{C}, 30 \mathrm{~s}$ & $47^{\circ} \mathrm{C}, 30 \mathrm{~s}$ & $72{ }^{\circ} \mathrm{C}, 90 \mathrm{~s}$ & [18] \\
\hline $\begin{array}{l}\text { HIP400F } \\
\text { HIP1134R }\end{array}$ & $\begin{array}{c}\text { GAAGAGGGTTTGGGTGGTG } \\
\text { AGCTAGCTTCGCATAATAACTTG }\end{array}$ & hipO gene & 735 & $94^{\circ} \mathrm{C}, 30 \mathrm{~s}$ & $55^{\circ} \mathrm{C}, 30 \mathrm{~s}$ & $72{ }^{\circ} \mathrm{C}, 45 \mathrm{~s}$ & [77] \\
\hline Cj-CdtAU2 & AGGACTTGAACCTACTTTTC & \multirow{2}{*}{ CjcdtA } & \multirow{2}{*}{631} & \multirow{3}{*}{$94^{\circ} \mathrm{C}, 30 \mathrm{~s}$} & \multirow{3}{*}{$53^{\circ} \mathrm{C}, 30 \mathrm{~s}$} & \multirow{3}{*}{$72{ }^{\circ} \mathrm{C}, 30 \mathrm{~s}$} & \multirow{3}{*}{ [78] } \\
\hline Cj-CdtAR2 & AGGTGGAGTAGTTAAAAACC & & & & & & \\
\hline $\begin{array}{l}\text { Cc-CdtAU1 } \\
\text { Cc-CdtAR1 }\end{array}$ & $\begin{array}{l}\text { ATTGCCAAGGCTAAAATCTC } \\
\text { GATAAAGTCTCCAAAACTGC }\end{array}$ & $C c c d t A$ & 329 & & & & \\
\hline Cf-CdtAU1 & AACGACAAATGTAAGCACTC & \multirow{2}{*}{$C f c d t A$} & \multirow{2}{*}{489} & & & & \\
\hline Cf-CdtAR1 & TATTTATGCAAGTCGTGCGA & & & \multirow{4}{*}{ NA } & \multirow{4}{*}{ NA } & \multirow{4}{*}{ NA } & \multirow{4}{*}[16]{} \\
\hline 16S520F & GTGCCAGCAGCCGCGG & \multirow{3}{*}{$\begin{array}{c}\text { Sequence for } \mathrm{Cj}^{-}, \\
\text {Cc- and Cf- } \\
16 \mathrm{~S} \text { rRNA }\end{array}$} & \multirow{3}{*}{ NA } & & & & \\
\hline 16S1199F & GCAACGAGCGCAACCC & & & & & & \\
\hline $\begin{array}{l}16 \mathrm{~S} 741 \mathrm{R} \\
16 \mathrm{~S} 1240 \mathrm{R}\end{array}$ & $\begin{array}{l}\text { GTATCTAATCCTGTTTGC } \\
\text { CCATTGTAGCACGTGT }\end{array}$ & & & & & & \\
\hline
\end{tabular}

Cj, C. jejuni; Cc, C. coli; Cf, C. fetus; NA, not applicable. 
In this study, the identification of $C$. jejuni was accomplished by two molecular assays. After the primary confirmation of Campylobacter spp., hippuricase (hipO) gene-based PCR was done using all the isolates to discriminate $C$. jejuni as per the method defined in Table 5 [18]. Secondly, $c d t A$ gene-based multiplex PCR assay was performed for Campylobacter identification by species (i.e., C. jejuni, C. coli, and C. fetus) using all isolates $(n=194)$ as per the method described in Table 5 [77]. In PCR assays, positive controls and DNA templates of C. jejuni ATCC 33560, C. coli ATCC 33559, and C. fetus ATCC 27374 strains were used. Escherichia coli ATCC 25922 was used as a negative control (Supplementary Figure S1). Information of all primers and corresponding PCR amplicon sizes are presented in Table 5. PCR products were visualized at gel electrophoresis (1.5\% agarose, Invitrogen, Carlsbad, CA, USA), and after staining with ethidium bromide $\left(0.5 \mu \mathrm{g} \mathrm{mL}^{-1}\right)$ and destaining with distilled water for $10 \mathrm{~min}$, further gel images were taken using a UV transilluminator (Biometra, Göttingen, Germany).

\subsubsection{Sequencing of $16 \mathrm{~S}$ rRNA Gene}

The primers used for the sequencing of the 16S rRNA gene of Campylobacter species $(n=21)$ are presented in Table 5. After amplification of the 16S rRNA gene, the PCR product was purified using a Wizard ${ }^{\circledR}$ SV Gel and PCR Clean-Up System according to the manufacturer's instructions (Promega, Madison, WI, USA). The purified PCR products were sequenced through standard Sanger's sequencing method with the BigDye terminator v3.1 sequencing kit and a 3730xl automated sequencer (Applied Biosystems, Foster City, CA, USA). Homology searches were accomplished against highly similar sequences (megablast) in the GenBank database using the BLAST analysis tools, which are available from the National Center for Biotechnology Information (NCBI) website (https: / / www.ncbi.nlm. nih.gov/) (accessed on 10 December 2020). Finally, the sequences were deposited to the GenBank, and accession numbers were obtained against each sequence.

\subsection{Statistical Evaluation}

In this study, the unit of analysis was a herd or farm. A herd/farm was considered to be positive if the individual feces sample collected from each animal tested positive in both tentative (culture-based and biochemical tests) and confirmatory molecular assays (PCR). Therefore, the dependent variable of this study was dichotomous data, either Campylobacter positive or negative. Several continuous variables were converted into categorical variables (age of farm, farm size, stocking density) to accomplish the analysis.

Data from field surveys and laboratory evaluations were recorded in Microsoft Excel 2010 (MS Excel) spreadsheets and data were cleaned, coded, and checked for consistency. The data were further exported into the Epi Info 7 program [79] for statistical analysis. The odds ratio (OR) was calculated through univariate logistic regression model for estimating the relationship on Campylobacter positive status, and a $p$-value of $<0.05$ was considered as statistically significance. The significant variables were further utilized in the multivariable logistic regression model. Descriptive analysis was done, the outputs were presented in frequencies and proportion, and $95 \%$ binomial confidence intervals (CI) were confirmed using the excel data analysis tool pack for estimating the prevalence values of Campylobacter spp. in various samples and at the farm level. Categorical response variables were presented as proportions, and their associations determined by Pearson's Chi-square tests.

\section{Conclusions}

Cattle have been recognized as reservoirs of Campylobacter that facilitate environmental contamination through feces. This finding suggests the need for appropriate control measures to promote good animal husbandry practices, including stringent biosecurity and hygienic measurements. The importance of participatory training and good farm practices for cattle farmers and attendants highlights the environmental, animal, and human "One Health" approach to mitigate the prevalence of Campylobacter in the farm environment and prevent further transmission to animals and humans. 
Supplementary Materials: The following are available online at https: / www.mdpi.com/2076-0 817/10/3/313/s1, Figure S1: Molecular identification including (a) detection of Campylobacter spp. by $16 \mathrm{~S}$ rRNA gene; (b) confirmation of $C$. jejuni by hippuricase (hipO) gene-based PCR, lanes 1 and 17: $100 \mathrm{bp}$ DNA ladder (Promega, USA), lanes 2-14: representative positive isolates, lane 15: positive control (C. jejuni ATCC 33560), lane 16: negative control (Escherichia coli ATCC 25922); and (c) confirmation of $C$. jejuni, C. coli, and C. fetus by $c d t A$ gene-based multiplex PCR assay, lanes 1 and 17: $100 \mathrm{bp}$ DNA ladder (Promega, USA), lanes 2-12: representative positive isolates, lane 13: positive control (C. coli ATCC 33559), lane 14: positive control (C. jejuni ATCC33560), lane 15: positive control (C. fetus ATCC 27374), and lane 16: negative control (Escherichia coli ATCC25922). Figure S2: Schematic diagram of sample collection and testing workflow. Table S1: District and sub-district-wise sample collection status and test results. Table S2: Herd-level data. Table S3: Questionnaire on assessment of herd-level risk factors in dairy farms for Campylobacter infection in selected districts of Bangladesh.

Author Contributions: Conceptualization, S.M.L.K.; Data collection, N.H., M.N.U., M.A., and A.K.M.Z.H.; Funding acquisition, S.M.L.K.; Methodology, N.H., S.S.I., and M.A.; Software, S.S.I. and M.N.U.; Supervision, S.M.L.K.; Writing—original draft, N.H., M.N.U., and S.S.I.; Writing—review and editing, S.B.N., M.M.H., S.Y., and S.M.L.K. All authors have read and agreed to the published version of the manuscript.

Funding: The research work was funded by Krishi Gobeshona Foundation (KGF Project ID: TF-45L/17), AIC Building ( $3^{\text {rd }}$ Floor), BARC Campus, Farmgate, Dhaka-1215, Bangladesh.

Institutional Review Board Statement: The Ethical Committee of the Bangladesh Agricultural University approved the study under reference no. AWEEC/BAU/2019(45).

Informed Consent Statement: The objectives of this study were duly clarified to the respondents so they could voluntarily involve themselves with this study or withdraw at any time if they disagreed. Farms were engaged through the organization of meetings in each local (sub-district/municipality) livestock office of the Mymensingh and Dhaka districts. However, written consent was obtained from each dairy farmer/farm attendant of each surveyed farm prior to the data collection and subsequent sampling in this study.

Data Availability Statement: The data presented in this study are contained in this manuscript and supplementary materials.

Acknowledgments: The authors are grateful to the sub-district (Upazila), the Dhaka City Corporation, and the district livestock officers of the studied districts for their assistance engaging the cattle farms in this study. The authors would also like to thank the dairy farmers, managers, and farm attendants for their assistance during field survey data collection and sampling.

Conflicts of Interest: The authors declare that they have no competing interests. The funders had no involvement with the study design, data collection and analysis, manuscript drafting, or decision to publish the manuscript.

\section{References}

1. Kirk, M.D.; Pires, S.M.; Black, R.E.; Caipo, M.; Crump, J.A.; Devleesschauwer, B.; Döpfer, D.; Fazil, A.; Fischer-Walker, C.L.; n World Health Organization estimates of the global and regional disease burden of 22 foodborne bacterial, protozoal, and viral diseases, 2010: A data synthesis. PLoS Med. 2015, 12, e1001921. [CrossRef]

2. Tack, D.M.; Marder, E.P.; Griffin, P.M.; Cieslak, P.R.; Dunn, J.; Hurd, S.; Scallan, E.; Lathrop, S.; Muse, A.; Ryan, P. Preliminary incidence and trends of infections with pathogens transmitted commonly through food-Foodborne Diseases Active Surveillance Network, 10 US Sites, 2015-2018. Morb. Mortal. Wkly. Rep. 2019, 68, 369. [CrossRef]

3. CDC. Antibiotic Resistance Threats in the United States; U.S. Department of Health and Human Services, Ed.; CDC: Atlanta, GA, USA, 2019.

4. Mäesaar, M.; Tedersoo, T.; Meremäe, K.; Roasto, M. The source attribution analysis revealed the prevalent role of poultry over cattle and wild birds in human campylobacteriosis cases in the Baltic States. PLoS ONE 2020, 15, e0235841. [CrossRef] [PubMed]

5. Sahin, O.; Yaeger, M.; Wu, Z.; Zhang, Q. Campylobacter-associated diseases in animals. Annu. Rev. Anim. Biosci. 2017, 5, 21-42. [CrossRef] 
6. Manyi-Loh, C.E.; Mamphweli, S.N.; Meyer, E.L.; Makaka, G.; Simon, M.; Okoh, A.I. An overview of the control of bacterial pathogens in cattle manure. Int. J. Environ. Res. Public Health 2016, 13, 843. [CrossRef]

7. Ogden, I.D.; Dallas, J.F.; MacRae, M.; Rotariu, O.; Reay, K.W.; Leitch, M.; Thomson, A.P.; Sheppard, S.K.; Maiden, M.; Forbes, K.J. Campylobacter excreted into the environment by animal sources: Prevalence, concentration shed, and host association. Foodborne Pathog. Dis. 2009, 6, 1161-1170. [CrossRef]

8. Quinn, J. Clinical strategies for serious infection: A North American perspective. Diagn. Microbiol. Infect. Dis. 1998, 31, 389-395. [CrossRef]

9. Friedman, C.R.J.; Neiman, H.C.; Wegener, R.V. Tauxe. Epidemiology of Campylobacter Jejuni Infections in the United States and Other Industrialised Nation; ASM Press: Washington, DC, USA, 2000.

10. The European Union summary report on trends and sources of zoonoses, zoonotic agents and food-borne outbreaks in 2013. EFSA J. 2015, 13, 3991. [CrossRef]

11. Gillespie, I.A.; O’Brien, S.J.; Frost, J.A.; Adak, G.K.; Horby, P.; Swan, A.V.; Painter, M.J.; Neal, K.R.; Collaborators, C.S.S.S. A case-case comparison of Campylobacter coli and Campylobacter jejuni infection: A tool for generating hypotheses. Emerg. Infect. Dis. 2011, 8, 937-942. [CrossRef]

12. Bullman, S.; Corcoran, D.; O'Leary, J.; O’Hare, D.; Lucey, B.; Sleator, R.D. Emerging dynamics of human campylobacteriosis in Southern Ireland. FEMS Immunol. Med. Mic. 2011, 63, 248-253. [CrossRef]

13. Wassenaar, T.M.; Newell, D.G. Genotyping of Campylobacter spp. Appl. Environ. Microbiol. 2000, 66, 1-9. [CrossRef]

14. Patton, C.; Wachsmuth, I.; Evins, G.; Kiehlbauch, J.; Plikaytis, B.; Troup, N.; Tompkins, L.; Lior, H. Evaluation of 10 methods to distinguish epidemic-associated Campylobacter strains. J. Clin. Microbiol. 1991, 29, 680-688. [CrossRef] [PubMed]

15. Al Amri, A.; Senok, A.C.; Ismaeel, A.Y.; Al-Mahmeed, A.E.; Botta, G.A. Multiplex PCR for direct identification of Campylobacter spp. in human and chicken stools. J. Med. Microbiol. 2007, 56, 1350-1355. [CrossRef]

16. Kabir, S.M.L.; Kikuchi, K.; Asakura, M.; Shiramaru, S.; Tsuruoka, N.; Goto, A.; Hinenoya, A.; Yamasaki, S. Evaluation of a cytolethal distending toxin $(c d t)$ gene-based species-specific multiplex PCR assay for the identification of Campylobacter strains isolated from diarrheal patients in Japan. Jpn. J. Infect. Dis. 2011, 64, 19-27.

17. Asakura, M.; Samosornsuk, W.; Taguchi, M.; Kobayashi, K.; Misawa, N.; Kusumoto, M.; Nishimura, K.; Matsuhisa, A.; Yamasaki, S. Comparative analysis of cytolethal distending toxin (cdt) genes among Campylobacter jejuni, C. coli and C. fetus strains. Microb. Pathog. 2007, 42, 174-183. [CrossRef] [PubMed]

18. Samosornsuk, W.; Asakura, M.; Yoshida, E.; Taguchi, T.; Nishimura, K.; Eampokalap, B.; Phongsisay, V.; Chaicumpa, W.; Yamasaki, S. Evaluation of a cytolethal distending toxin (cdt) gene-based species-specific multiplex PCR assay for the identification of Campylobacter strains isolated from poultry in Thailand. Microbiol. Immunol. 2007, 51, 909-917. [CrossRef]

19. Berthenet, E.; Thépault, A.; Chemaly, M.; Rivoal, K.; Ducournau, A.; Buissonnière, A.; Bénéjat, L.; Bessède, E.; Mégraud, F.; Sheppard, S.K.; et al. Source attribution of Campylobacter jejuni shows variable importance of chicken and ruminants reservoirs in non-invasive and invasive French clinical isolates. Sci. Rep. 2019, 9, 8098. [CrossRef]

20. EFSA Panel on Biological Hazards (BIOHAZ). Scientific Opinion on Quantification of the risk posed by broiler meat to human campylobacteriosis in the EU. EFSA J. 2010, 8, 1437. [CrossRef]

21. Kaakoush, N.O.; Castaño-Rodríguez, N.; Mitchell, H.M.; Man, S.M. Global epidemiology of Campylobacter infection. Clin. Microbiol. Rev. 2015, 28, 687-720. [CrossRef]

22. Nichols, G.L.; Richardson, J.F.; Sheppard, S.K.; Lane, C.; Sarran, C. Campylobacter epidemiology: A descriptive study reviewing 1 million cases in England and Wales between 1989 and 2011. BMJ Open 2012, 2, e001179. [CrossRef] [PubMed]

23. Sheppard, S.K.; Dallas, J.F.; Strachan, N.J.; MacRae, M.; McCarthy, N.D.; Wilson, D.J.; Gormley, F.J.; Falush, D.; Ogden, I.D.; Maiden, M.C. Campylobacter genotyping to determine the source of human infection. Clin. Infect. Dis. 2009, 48, 1072-1078. [CrossRef]

24. Thépault, A.; Méric, G.; Rivoal, K.; Pascoe, B.; Mageiros, L.; Touzain, F.; Rose, V.; Béven, V.; Chemaly, M.; Sheppard, S.K. Genome-wide identification of host-segregating epidemiological markers for source attribution in Campylobacter jejuni. Appl. Environ. Microbiol. 2017, 83, e03085-16. [CrossRef] [PubMed]

25. Hlashwayo, D.F.; Sigaúque, B.; Bila, C.G. Epidemiology and antimicrobial resistance of Campylobacter spp. in animals in Sub-Saharan Africa: A Systemic Review. Heliyon 2020, 6, e03537. [CrossRef] [PubMed]

26. Hannon, S.J.; Allan, B.; Waldner, C.; Russell, M.L.; Potter, A.; Babiuk, L.A.; Townsend, H.G. Prevalence and risk factor investigation of Campylobacter species in beef cattle feces from seven large commercial feedlots in Alberta, Canada. Can. J. Vet. Res. 2009, 73, 275-282. [PubMed]

27. Wesley, I.; Wells, S.; Harmon, K.; Green, A.; Schroeder-Tucker, L.; Glover, M.; Siddique, I. Fecal shedding of Campylobacter and Arcobacter spp. in dairy cattle. Appl. Environ. Microbiol. 2000, 66, 1994-2000. [CrossRef] [PubMed]

28. Klein, D.; Alispahic, M.; Sofka, D.; Iwersen, M.; Drillich, M.; Hilbert, F. Prevalence and risk factors for shedding of thermophilic Campylobacter in calves with and without diarrhea in Austrian dairy herds. J. Dairy Sci. 2013, 96, 1203-1210. [CrossRef] [PubMed] 
29. Kashoma, I.P.; Kassem, I.I.; Kumar, A.; Kessy, B.M.; Gebreyes, W.; Kazwala, R.R.; Rajashekara, G. Antimicrobial resistance and genotypic diversity of Campylobacter isolated from pigs, dairy, and beef cattle in Tanzania. Front. Microbiol. 2015, 6, 1240. [CrossRef]

30. Blaser, M.J.; Taylor, D.N.; Feldman, R.A. Epidemiology of Campylobacter jejuni infections. Epidemiol. Rev. 1983, 5, 157-176. [CrossRef]

31. Stanley, K.N.; Wallace, J.S.; Currie, J.E.; Diggle, P.J.; Jones, K. The seasonal variation of thermophilic Campylobacters in beef cattle, dairy cattle and calves. J. Appl. Microbiol. 1998, 85, 472-480. [CrossRef]

32. Stampi, S.; Varoli, O.; Zanetti, F.; De Luca, G. Arcobacter cryaerophilus and thermophilic Campylobacters in a sewage treatment plant in Italy: Two secondary treatments compared. Epidemiol. Infect. 1993, 110, 633-639. [CrossRef] [PubMed]

33. Tauxe, R.V. Epidemiology of Campylobacter jejuni infections in the United States and other industrialized nations. In Campylobacter jejuni: Current Status; Nachamkin, I., Blaser, M.J., Tompkins, L.S., Eds.; American Society for Microbiology (ASM) Press: Washington, DC, USA, 1992; pp. 9-16.

34. National Livestock Development Policy, Department of Livestock Services, Ministry of Fisheries and Livestock, Peoples Republic of Bangladesh. 2007. Available online: http:/ / old.dls.gov.bd/files/Livestock_Policy_Final.pdf (accessed on 29 September 2020).

35. Livestock Economy at a Glance 2019-2020. Department of Livestock Services, Ministry of Fisheries and Livestock, Government of the People's Republic of Bangladesh. 2020. Available online: http://dls.portal.gov.bd/sites/default/files/files/dls.portal.gov. bd/page/ee5f4621_fa3a_40ac_8bd9_898fb8ee4700/2020-07-22-19-34-e4cd5ed65f45419ee038e00b8939c1a0.pdf (accessed on 29 December 2020).

36. Mourkas, E.; Taylor, A.J.; Méric, G.; Bayliss, S.C.; Pascoe, B.; Mageiros, L.; Calland, J.K.; Hitchings, M.D.; Ridley, A.; Vidal, A.; et al. Agricultural intensification and the evolution of host specialism in the enteric pathogen Campylobacter jejuni. Proc. Natl. Acad. Sci. USA 2020, 117, 11018-11028. [CrossRef]

37. Batut, B.; Knibbe, C.; Marais, G.; Daubin, V. Reductive genome evolution at both ends of the bacterial population size spectrum. Nat. Rev. Microbiol. 2014, 12, 841-850. [CrossRef] [PubMed]

38. Ocejo, M.; Oporto, B.; Hurtado, A. Occurrence of Campylobacter jejuni and Campylobacter coli in cattle and sheep in Northern Spain and changes in antimicrobial resistance in two studies 10-years apart. Pathogens 2019, 8, 98. [CrossRef] [PubMed]

39. Kabir, S.M.L.; Lubna, M.M.; Islam, M.; Haque, A.K.M.Z.; Neogi, S.B.; Yamasaki, S. Isolation, molecular identification and antimicrobial resistance patterns of Campylobacter species of dairy origin: First report from Bangladesh. Vet. Sci. Dev. 2018, 8, 7838. [CrossRef]

40. Mohakud, N.K.; Patra, S.D.; Kumar, S.; Sahu, P.S.; Misra, N.; Shrivastava, A.K. Detection and molecular typing of campylobacter isolates from human and animal faeces in coastal belt of Odisha, India. Indian J. Med. Microbiol. 2019, 37, 345-350. [CrossRef]

41. Thépault, A.; Poezevara, T.; Quesne, S.; Rose, V.; Chemaly, M.; Rivoal, K. Prevalence of thermophilic Campylobacter in cattle production at slaughterhouse level in France and link between $C$. jejuni bovine strains and campylobacteriosis. Front. Microbiol. 2018, 9, 471. [CrossRef]

42. Hansson, I.; Engvall, E.O.; Ferrari, S.; Harbom, B.; Lahti, E. Detection of Campylobacter species in different types of samples from dairy farms. Vet. Rec. 2020, 186, 605. [CrossRef] [PubMed]

43. Oporto, B.; Esteban, J.; Aduriz, G.; Juste, R.; Hurtado, A. Prevalence and strain diversity of thermophilic campylobacters in cattle, sheep and swine farms. J. Appl. Microbiol. 2007, 103, 977-984. [CrossRef]

44. Ramonaitè, S.; Rokaitytè, A.; Tamulevičienè, E.; Malakauskas, A.; Alter, T.; Malakauskas, M. Prevalence, quantitative load and genetic diversity of Campylobacter spp. in dairy cattle herds in Lithuania. Acta. Vet. Scand. 2013, 55, 87. [CrossRef]

45. Padungtod, P.; Kaneene, J.B. Campylobacter in food animals and humans in northern Thailand. J. Food Prot. 2005, 68, 2519-2526. [CrossRef] [PubMed]

46. Boonmar, S.; Chanda, C.; Markvichitr, K.; Chaunchom, S.; Yingsakmongkon, S.; Yamamot, S.; Morita, Y. Prevalence of Campylobacter spp. in slaughtered cattle and buffaloes in Vientiane, Lao People's Democratic Republic. J. Vet. Med. Sci. 2007, 69, 853-855. [CrossRef]

47. An, J.-U.; Ho, H.; Kim, J.; Kim, W.H.; Kim, J.; Lee, S.; Mun, S.H.; Guk, J.H.; Hong, S.; Cho, S. Dairy cattle, a potential reservoir of human campylobacteriosis: Epidemiological and molecular characterization of Campylobacter jejuni from cattle farms. Front. Microbiol. 2018, 9, 3136. [CrossRef]

48. Membre, J.M.; Laroche, M.; Magras, C. Meta-analysis of Campylobacter spp. Survival Data within a Temperature Range of 0 to $42{ }^{\circ}$ C. J. Food Prot. 2013, 76, 1726-1732. [CrossRef]

49. Inglis, G.D.; McAllister, T.A.; Larney, F.J.; Topp, E. Prolonged survival of Campylobacter species in bovine manure compost. Appl. Environ. Microbiol. 2010, 76, 1110-1119. [CrossRef]

50. Guan, T.Y.; Holley, R.A. Pathogen survival in swine manure environments and transmission of human enteric illness-a review. J Environ Qual. 2003, 32, 383-392. [CrossRef]

51. Flink, C.N.K.F. A sjukdomsframkallande bakterier I opastoriserad mjolk(in Swedish), (presence of pathogenic bacteria in unpasteurized). Swed. Food Agency Rep. 2016, 12. Available online: https://www.livsmedelsverket.se/globalassets/ publikationsdatabas / rapporter/2016/forekomst-av-sjukdomsframkallande-bakterier-i-opastoriserad-mjolk_rapport-12_2016. pdf (accessed on 29 December 2020). 
52. Heuvelink, A.E.; van Heerwaarden, C.; Zwartkruis-Nahuis, A.; Tilburg, J.J.; Bos, M.H.; Heilmann, F.G.; Hofhuis, A.; Hoekstra, T.; de Boer, E. Two outbreaks of campylobacteriosis associated with the consumption of raw cows' milk. Int. J. Food Microbiol. 2009, 134, 70-74. [CrossRef] [PubMed]

53. Gilpin, B.J.; Scholes, P.; Robson, B.; Savill, M.G. The transmission of thermotolerant Campylobacter spp. to people living or working on dairy farms in New Zealand. Zoonoses Public Health. 2008, 55, 352-360. [CrossRef] [PubMed]

54. Davis, K.R.; Dunn, A.C.; Burnett, C.; McCullough, L.; Dimond, M.; Wagner, J.; Smith, L.; Carter, A.; Willardson, S.; Nakashima, A.K. Campylobacter jejuni infections associated with raw milk consumption-Utah, 2014. Morb. Mortal. Wkly. 2016, 65, 301-305. [CrossRef]

55. Mungai, E.A.; Behravesh, C.B.; Gould, L.H. Increased outbreaks associated with nonpasteurized milk, United States, $2007-2012$. Emerg. Infect. Dis. 2015, 21, 119-122. [CrossRef] [PubMed]

56. Smith, K.E.; Stenzel, S.A.; Bender, J.B.; Wagstrom, E.; Soderlund, D.; Leano, F.T.; Taylor, C.M.; Belle-Isle, P.A.; Danila, R. Outbreaks of enteric infections caused by multiple pathogens associated with calves at a farm day camp. Pediatr. Infect. Dis. J. 2004, 23, 1098-1104. [CrossRef] [PubMed]

57. Eberhart-Phillips, J.; Walker, N.; Garrett, N.; Bell, D.; Sinclair, D.; Rainger, W.; Bates, M. Campylobacteriosis in New Zealand: Results of a case-control study. J. Epidemiol. Community Health 1997, 51, 686-691. [CrossRef] [PubMed]

58. Ruegg, P. Practical food safety interventions for dairy production. J. Dairy Sci. 2003, 86, E1-E9. [CrossRef]

59. Vissers, M.; Driehuis, F. On-Farm Hygienic Milk Production. Milk Processing and Quality Management; Blackwell Publishing Ltd.: Hoboken, NJ, USA, 2009; pp. 1-22.

60. Grove-White, D.; Leatherbarrow, A.; Cripps, P.; Diggle, P.; French, N. Temporal and farm-management-associated variation in the faecal-pat prevalence of Campylobacter jejuni in ruminants. Epidemiol. Infect. 2010, 138, 549-558. [CrossRef]

61. California Department of Public Health. Environmental Investigation of a Campylobacter jejuni Outbreak in 2012 Associated with Claravale Farms Raw Whole Milk; Final Report; California Department of Public Health: Sacramento, CA, USA, 2013; Available online: https:/ / www.cdph.ca.go/rogram/E/FDC/DPH\%20Document\%20Librar/D/oodSafetyProgra/nvInvReport/dbEIRCV2 013.pdf. (accessed on 29 December 2020).

62. Sommer, H.M.; Høg, B.B.; Larsen, L.S.; Sørensen, A.I.V.; Williams, N.; Merga, J.; Cerdà-Cuéllar, M.; Urdaneta, S.; Dolz, R.; Wieczorek, K. Analysis of farm specific risk factors for Campylobacter colonization of broilers in six European countries. Microb. Risk Anal. 2016, 2, 16-26. [CrossRef]

63. Hussain, M.; Hoq, M.E. Impacts of climate change on coastal and marine fisheries resources in Bangladesh. In Sustainable Management of Fisheries Resources of the Bay of Bengal; Department of Fisheries: Dhaka, Bangladesh, 2010; pp. 53-73.

64. Park, J.; Jung, W. The operators' non-compliance behavior to conduct emergency operating procedures-Comparing with the work experience and the complexity of procedural steps. Reliab. Eng. Syst. Safe. 2003, 82, 115-131. [CrossRef]

65. Newell, D.; Elvers, K.; Dopfer, D.; Hansson, I.; Jones, P.; James, S.; Gittins, J.; Stern, N.; Davies, R.; Connerton, I.; et al. Biosecuritybased interventions and strategies to reduce Campylobacter spp. on poultry farms. Appl. Environ. Microbiol. 2011, 77, 8605-8614. [CrossRef]

66. Sibanda, N.; McKenna, A.; Richmond, A.; Ricke, S.C.; Callaway, T.; Stratakos, A.C.; Gundogdu, O.; Corcionivoschi, N. A review of the effect of management practices on Campylobacter prevalence in poultry farms. Front. Microbiol. 2018, 9, 2002. [CrossRef]

67. Pires, A.F.A.; Patterson, L.; Kukielka, E.A.; Aminabadi, P.; Navarro-Gonzalez, N.; Jay-Russell, M.T. Prevalence and risk factors associated with Campylobacter spp. and Salmonella enterica in livestock raised on diversified small-scale farms in California. Epidemiol. Infect. 2019, 147, 1-9. [CrossRef]

68. Gormley, F.J.; MacRae, M.; Forbes, K.J.; Ogden, I.D.; Dallas, J.F.; Strachan, N.J. Has retail chicken played a role in the decline of human campylobacteriosis? Appl. Environ. Microbiol. 2008, 74, 383-390. [CrossRef] [PubMed]

69. District-Wise Livestock Data Base; Department of Livestock Services, Ministry of Fisheries and Livestock, Government of the People's Republic of Bangladesh, 2020. Available online: http:/ / old.dls.gov.bd/ (accessed on 29 December 2020).

70. Hamid, M.; Rahman, A.; Zaman, M.; Hossain, K. Cattle Genetic Resources and their Conservation in Bangladesh. Asian J. Anim. Sci. 2017, 11, 54-64. [CrossRef]

71. Thrusfield, M. Veterinary Epidemiology, 3rd ed.; Wiley-Blackwell: Oxford, UK, 2009.

72. Bolton, F.; Hutchinson, D.; Parker, G. Reassessment of selective agars and filtration techniques for isolation of Campylobacter species from faeces. Eur. J. Clin. Microbiol. 1988, 7, 155-160. [CrossRef]

73. Nachamkin, I. Campylobacter and Arcobacter. In Clinical Microbiology Reviews; Murray, P.R., Baron, E.J., Jorgensen, J.H., Pfaller, M.A., Yolken, R.H., Eds.; American Society for Microbiology: Washington, DC, USA, 2003; pp. 902-914.

74. Foster, G.; Holmes, B.; Steigerwalt, A.G.; Lawson, P.A.; Thorne, P.; Byrer, D.E.; Ross, H.M.; Xerry, J.; Thompson, P.M.; Collins, M.D. Campylobacter insulaenigrae sp. nov., isolated from marine mammals. Int. J. Syst. Evol. Microbiol. 2004, 54, 2369-2373. [CrossRef] [PubMed]

75. Swai, E.; Hulsebosch, J.; Van der Heijden, W. Prevalence of genital campylobacteriosis and trichomonosis in crossbred breeding bulls kept on zero-grazed smallholder dairy farms in the Tanga region of Tanzania. J. S. Afr. Vet. Assoc. 2005, 76, 224-227. [CrossRef]

76. Hoshino, K.; Yamasaki, S.; Mukhopadhyay, A.K.; Chakraborty, S.; Basu, A.; Bhattacharya, S.K.; Nair, G.B.; Shimada, T.; Takeda, Y. Development and evaluation of a multiplex PCR assay for rapid detection of toxigenic Vibrio cholerae O1 and O139. FEMS Immunol. Med. Microbiol. 1998, 20, 201-207. [CrossRef] [PubMed] 
77. Linton, D.; Lawson, A.J.; Owen, R.J.; Stanley, J. PCR detection, identification to species level, and fingerprinting of Campylobacter jejuni and Campylobacter coli direct from diarrheic samples. J. Clin. Microbiol. 1997, 35, 2568-2572. [CrossRef]

78. Asakura, M.; Samosornsuk, W.; Hinenoya, A.; Misawa, N.; Nishimura, K.; Matsuhisa, A.; Yamasaki, S. Development of a cytolethal distending toxin $(c d t)$ gene-based species-specific multiplex PCR assay for the detection and identification of Campylobacter jejuni, Campylobacter coli and Campylobacter fetus. FEMS Immunol. Med. Microbiol. 2008, 52, 260-266. [CrossRef] [PubMed]

79. Centers for Disease Control and Prevention (CDC). Epi Info ${ }^{\text {TM }} 7$. User Guide. Available online: https://www.cdc.gov/epiinfo/ support/userguide.html (accessed on 29 December 2020). 